\title{
SCIENTIFIC AND METHODOLOGICAL WORK OF ALBERT YAKHIN
}

\author{
Ayrat Faikovich Yusupov, \\ Kazan Federal University, \\ 18 Kremlyovskaya Str., Kazan, 420008, Russian Federation, \\ faikovich@mail.ru.
}

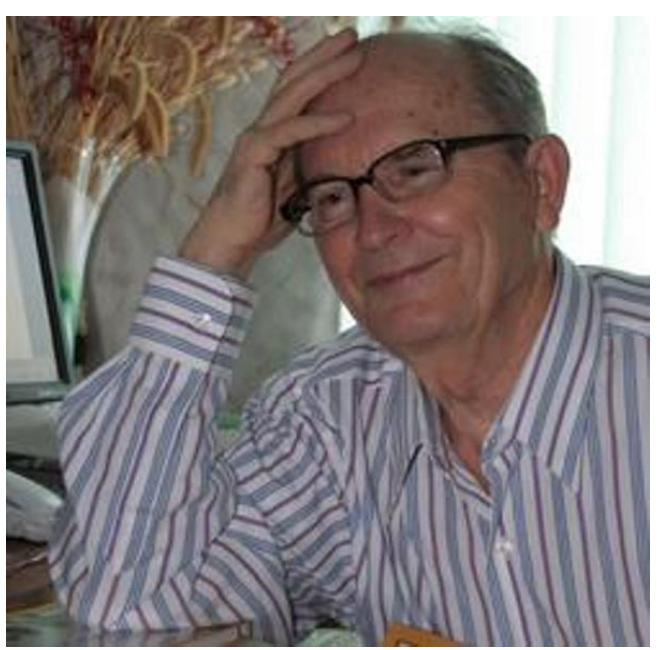

Yakhin Albert Gatufovich (1931 - 2010) was a scientist, Candidate of Philology, methodologist, member of the Union of Writers of the USSR (1977), journalist, Honored Worker of Culture of the RSFSR (1973). Albert Yakhin was born on November 8, 1931, in the village of Arsk, the Arsk district of the Republic of Tatarstan. In 1949, he left the Tymytyk secondary school of the Aznakayevsky district, the TASSR. In 1949-1954, he studied at the Department of the Tatar Language and Literature of Kazan State University named after V. I. Ulyanov-Lenin. After graduating from the university in 1954-1956, he worked as a deputy director of academic affairs at the Tymytyk secondary school of the Aznakayevsky district. In 19561959, he completed a post-graduate course. In 1964, he presented his Ph.D. thesis "Shamil Usmanov's Work". In 1959-1975, A. Yakhin worked in the editorial office of the satirical magazine "Chayan": in 1959-1968. he was an executive secretary, in 1968-1975 - the editorin-chief of the journal.

In 1975-2004, A. Yakhin
Яхин Альберт Гатуф улы (1931 - 2010) - әдәбият галиме, филология фәннәре кандидаты, методист, СССР Язучылар берлеге әгъзасы (1977), журналист, РСФСРның атказанган мәдәният хезмәткәре (1973). Альберт Гатуф улы Яхин 1931 елның 8 ноябрендә Татарстан Республикасының Арча районы Арча поселогында хезмәткәр гаиләсендә туа. 1949 елда Азнакай районы Тымытык урта мәктәбен тәмамлап, 19491954 елларда В.И. УльяновЛенин исемендәге Казан дәүләт университетының татар теле һәм әдәбияты бүлегендә белем ала. 1954-1956 елларда Азнакай районы Тымытык урта мәктәбендә уку-укыту эшләре буенча директор урынбасары булып эшли. 1956-1959 елларда В.И. Ульянов-Ленин исемендәге Казан дәүләт университетының татар әдәбияты кафедрасы каршындагы аспирантурада белем ала. 1964 елда «Шамил Усманов ижаты» дигән темага кандидатлык диссертациясен яклый. 1959-1975 еллар аралыгында А. Яхин «Чаян» журналы редакциясендә хезмәт
Яхин Альберт Гатуфович (1931-2010) - ученый, кандидат филологических наук, методист, член Союза писателей СССР (1977), журналист, заслуженный деятель культуры РСФСР (1973). Альберт Гатуфович Яхин родился 8 ноября 1931 года в поселке Арск Арского района Республики Татарстан. В 1949 году окончил Тымытыкскую среднюю школу Азнакаевского района ТАССР. В 1949-1954 гг. учился на отделении татарского языка и литературы Казанского государственного университета имени В. И. Ульянова-Ленина. После окончания вуза в 19541956 гг. работал заместителем директора по учебной работе в Тымытыкской средней школе Азнакаевского района. В 19561959 гг. учился в аспирантуре. В 1964 году защитил кандидатскую диссертацию на тему «Творчество Шамиля Усманова». В 1959-1975 гг. А. Яхин работал в редакции сатирического журнала «Чаян»: в 1959-1968 гг. был ответственным секретарем, в 1968-1975 главным редактором журнала.

В 1975-2004 гг. А. Г. Яхин вел научно-педагогическую работу в 
conducted scientific and pedagogical work at Kazan State University. 1975-1981, he headed the Department of Tatar Literature at Kazan State University named after V. I. Ulyanov-Lenin. In 19811990, A. Yakhin continued to work at the same department as a teacher, from 1991 to 2004, he was an Associate Professor in the Department of Methods of Teaching the Tatar Language and Literature at Kazan State University named after V. I. Ulyanov-Lenin. From 1992, he developed an alternative curriculum, textbooks, and teaching aids on Tatar literature for grades 1-11 of Tatar schools. куя: 1959-1968 елларда жаваплы сәркатип, 1968-1975 елларда баш мөхәррир вазифаларын башкара. 1975 елдан А. Яхин В.И. Ульянов-Ленин исемендәге Казан дәүләт университетына эшкә алына. 1981 елның февраленә кадәр тарихфилология факультетының татар әдәбияты кафедрасын житәкли. 1981-1991 елларда хезмәт юлын шул ук кафедрада укытучы буларак дәвам итә, 1991-2004 елларда татар телен һәм әдәбиятын укыту методикасы кафедрасы доценты булып эшли, студентларга 1920-30 еллар татар әдәбияты курсыннан лекцияләр укый. Шушы еллар аралыгында ул татар мәктәпләренең $1-11$ сыйныфлары өчен структур методка нигезләнгән яңа буын, альтернатив дәреслекләр эшли һәм апробацияли. 2004 елдан А. Яхин лаеклы ялга китә һәм гомеренең соңгы көннәренә кадәр методик эшчәнлеген дәвам иттерә.
Казанском государственном университете. С 1975 по 1981 гг. возглавлял кафедру татарской литературы Казанского государственного университета имени В. И. Ульянова-Ленина. В 1981-1990 гг. А. Г. Яхин продолжал работу на той же кафедре преподавателем, с 1991 по 2004 - доцентом кафедры методики преподавания татарского языка и литературы Казанского государственного университета имени В. И. Ульянова-Ленина. Начиная с 1992 года разработал альтернативную программу, учебники и методические пособия по татарской литературе для 1-11 классов татарских школ.
Albert Gatufovich Yakhin (1931-2010) was a literary critic, Candidate of Philology, methodologist, member of the Union of Writers of the USSR, journalist, and Honored Worker of Culture of the RSFSR (1973). He made a great contribution to the development of literary studies, proposing the concept of a systematic study of the oral folklore genres and literary texts. He is known as a methodologist who, with his programs and textbooks, laid down new paths in the field of national methodology, created his methodological school.

Albert Yakhin was born into the family of a civil servant in the village of Arsk, the Arsky District of the Republic of Tatarstan on November 8, 1931. The family moved to Aznakaevo, where, in 1949, he finished the Tumutuk secondary school. In the same year, he entered Kazan State University named after V. I. Ulyanov-Lenin, the Department of the Tatar Language and Literature. After receiving higher education, he returned to work at the Tumutuk secondary school, where he had studied before, and for two years worked as a deputy director of academic affairs. However, the craving for scientific research led A. Yakhin back to the university: in the period of 1956-1959, he studied in the graduate school at the Department of Tatar Literature of Kazan State University. In the same years, his scientific articles and publications began to appear in the Tatar media. He was known as a witty critic. After the post-graduate course, he began his professional career in journalism. In 1959, A. Yakhin joined the editorial board of "Chayan", the famous satirical magazine of the Republic of Tatarstan. In 1959-1968, he was its executive secretary; from 1968 to 1975, he worked as its editor-in-chief [Odiplərebez, p. 725]. In 1973, for his work in the field of print media, A. Yakhin was awarded the honorary title of Honored Worker of Culture of the RSFSR. Even though he held important positions in the field of journalism, he did not stop scientific research and in 1964 he defended his Ph.D. thesis on the topic 'Shamil Usmanov's Work". Later, together with A. Gilyazev, he created the drama "Shamil Usmanov" (1966-1967). This play was staged in 1967 at the Tatar State Academic Theater named after G. Kamal and for many years it had a successful run and was highly appreciated by theater critics.

During this period, A. Yakhin was actively involved in writing, his witty satirical stories and feuilletons were published in the magazines "Chayan", "Crocodil" (in the Russian language), in the Bashkir magazine "Sanak" (Hayfork), in the collections "Kolke kua kila" ("Laughter is Catching Up"), "Kunelle sahna" (“A Funny Scene"). In 
1975 his book "Ayttem isa kaittym" ("I Said") and in 1978 "Polnii poriadok" ("Everything Is in Order") were published. The fact that A. Yakhin was admitted to the Writers' Union of the USSR in 1977 testifies to his recognition and appreciation as a writer.

In 1975, A. Yakhin was invited to work as the head of the Department of Tatar Literature at Kazan State University and headed this department until 1981. Since 1981, he switched completely to teaching and intensified scientific research. In 1990, the Department of Teaching Methods of the Tatar Language and Literature was created at the newly opened Faculty of Tatar Philology and Oriental Languages. In 1991, A. Yakhin moved to this department and until his retirement taught a course of the history of Tatar literature of the 1920s and 1930s and conducted special courses related to the analysis of literary works.

The scientist passed away on October 2, 2010, in Kazan.

In the 1960s, A. Yakhin was engaged in literary studies. His speeches, scientific articles, literary works, and works, related to the study of the genres of oral folk art, contributed to his reputation as an academic literary critic who had an original, conceptual view, a desire for new thinking. The theory of structuralism, which was actualized in those years, had a great influence on his scientific development. In the mid-1970s, at Kazan State University, J. Nigmatullina was at the head of the widespread structural-semiotic study of literature and art, continuing the research of the Tartu-Moscow semiotic school [Nigmatullina, p. 251]. A. Yakhin was involved in this work and organized his research in this direction on a conceptual basis. The scientist chose folklore as the main object of study and was looking for new ways to study it as a single system. He outlined the main results of these studies in his books "Opyt sistematicheskogo issledovaniia folklornykh zhanrov" ("Experience in the Systematic Study of Folklore Genres") (1979) co-authored with M. Bakirov and "Opyt sistematicheskogo issledovaniia proizvedenii narodnogo tvorchestva" ("Experience in the Systematic Study of Works of Folk Art") (1982) co-authored with M. Magdeev. These books were highly appreciated by the public and accepted as a novelty in the folklore studies.

After continuing his research on the study of oral folklore, A. Yakhin published the monograph "Sistema tatarskogo folklora" ("The System of Tatar Folklore") in 1984. A. Yakhin was the first researcher of Tatar literary studies who considered
Tatar folklore as a holistic system of the development and change, based on Yu. Lotman's method of structural analysis. He made interesting conclusions on the study of oral folklore in conjunction with such sciences as the theory of literature, philosophy, sociology, aesthetics, and psychology. A. Yakhin introduced new ideas in Tatar literary studies. In the structure of the literary work, by separating the system and subsystem into vertical and horizontal levels, he concretizes the folklore genres of songs, riddles, proverbs and sayings, tales, etc. [Motigullina, Gainullina, p. 313]. In the second part of the monograph, he justifies his findings by analyzing specific folklore genres, which increases the practical significance of his work. This monograph by A. Yakhin remains relevant today for those studying the theory of folklore. He developed and improved his research in this direction in the books that were published later in the series "Khazina" ("Treasure").

In the early 1990s, A. Yakhin expanded the range of his methodological research. The winds of change of those years put textbooks in Tatar literature on the agenda, changing their content. Feeling this need well, in 1911, A. Yakhin gathered like-minded people and began to prepare textbooks and teaching aids for grades 5-11 of secondary schools with the Tatar language of instruction. In 2003-2004, curricula and textbooks for primary grades were published. However, this program was not easy to implement in school practices due to the focus on the study of literary work and literature as a whole with a structural method in mind. This is evidenced by the fact that school curricula and textbooks were at the center of heated debate at that time. Being an openminded scientist, he not only developed a curriculum and created textbooks based on it, but also personally tested his textbooks on the basis of the Shali school in the Pestrechinsky district. Alongside teaching at the university, he taught Tatar literature lessons at the Shali school using his textbooks and improving them in the learning process, only after that he offered them to be used at the regional level of the Republic of Tatarstan. For decades, A. Yakhin regularly conducted regional methodological seminars for teachers working in accordance with his curriculum.

The curriculum and textbooks, proposed by A. Yakhin, conceptually changed the teaching of Tatar literature: it was based on the development of students' ability for independent logical thinking, the perception of a literary work as a single unit 
and its structural and semiotic analysis. Owing to this, the student could perceive the literary work not as a text telling about some event, but as a perfectly logical, closely connected, multi-layered unit with internal components. It allowed having a fresh look, making it possible to realize that the author's thought was hidden in the depths like in an iceberg. The analysis was based on the principle of gradual increase of difficulty from simple to more complicated things, passing from the single writer's work to the literary period and the literary trend. In grades 5-6, students studied the theory of a literary work, mastered it through the analysis of individual works. In grades 7-8, theoretical knowledge that characterized literary works was mastered, providing the basis for studying works of individual writers, their ways of thinking, and their writing styles. In grades 9-11, concepts based on the estimation of literary periods were placed at the center of students' study, and the literary process was represented in its development and change. Thus, it was assumed that students would develop systematic, comprehensive knowledge about Tatar literature, and improve their skills of analyzing literary works. A. Yakhin created his own school in Tatar literary criticism and methodology, voiced new and original conceptual ideas.

\section{References}

Ediplarebez: biobibliografic beleshmalek (2009)

[Our Writers: A Biobibliographic Reference]. Vol. 2. Comp. R. N. Dautov, R. F. Rakhmani. 735 p. Kazan, Tatar publishing house. (In Tatar)

Iakhin, A. (1975). Ayttem isa kaittym: Satirik hikayalar ham akiyatlar [I Said: Satirical Stories and
Fairy Tales]. 192 p. Kazan, Tatar publishing house. (In Tatar)

Iakhin, A. (1978). Polnyi poriadok: rasskazy [Everything Is in Order: Stories]. 95 p. Kazan, Tatar publishing house. (In Russian)

Iakhin, A., Bakirov, M. (1979). Folklor zhanrlaryn sistema itep tikshery tazhribase: (Mazaklar, baetlar) [Experience of a Systematic Study of Folklore Genres: (Anecdotes, Tales)]. 198 p. Kazan, Kazan university. (In Tatar)

Iakhin, A., Mahdiev, M. (1982). Xalyk izhaty asarlaren sistema itep tiksheru tazhribase (Makal, tabyshmak, zhyrlar) [Experience of a Systematic Study of Works of Folk Art (Proverbs, Riddles, Songs)]. 112 p. Kazan, Kazan university. (In Tatar)

Iakhin, A. (1984). Sistema tatarskogo folklora [Tatar Folklore System]. 200 p. Kazan, Tatar publishing house. (In Russian)

Iakhin, A. (2003). Adabiiat dareslare: Ukytuchylyr, iugary uku iortlary studentlary, ukuchylar ochen metodik kullanma [Literature Lessons: A Methodological Guide for Teachers, University Students, School Students]. 157 p. Kazan, Magarif. (In Tatar)

Motigullina, A., Gainullina, G. (2016). Vklad A. Iakhina $v$ razvitie metodiki prepodavaniia tatarskoi literatury v shkole [A. Yakhin's Contribution to the Development of Methods of Teaching Tatar Literature at School]. Philology and culture. No. 4 (46), pp. 311-317 (In Russian)

Nigmatullina, Yu. (2004). Sistemno-kompleksnoe issledovanie khudozhestvennogo tvorchestva: istoriia nauchnogo napravleniia $v$ Kazanskom universitete [System-Integrated Study of Artistic Creativity: The History of the Scientific Trend at Kazan University]. 251 p. Kazan, Fən. (In Russian)

\section{АЛЬБЕРТ ГАТУФ УЛЫ ЯХИННЫН ФӘННИ-МЕТОДИК ЭШЧӘНЛЕГЕ}

Альберт Гатуф улы Яхин (1931 - 2010) әдәбият галиме, филология фәннәре кандидаты, методист, СССР Язучылар берлеге әгъзасы, журналист, РСФСРның атказанган мәдәният хезмәткәре (1973). Ул халык авыз ижаты жанрларын, әдәби текстны системалы тикшерү концепциясен тәкъдим итеп, әдәбият белеме фәнен үстерүгә зур өлеш керткән галим, татар әдәбиятыннан Үзгә концепциягә корылган

\author{
Айрат Фаик улы Юсупов, \\ Казан федераль университеты, \\ Россия, 420008, Казан ш., Кремль ур., 18 нче йорт, \\ faikovich@mail.ru.
}

программа hәм дәреслекләре белән милли методика өлкәсендә яңа юллар салган, үзенең методик мәктәбен булдырган методист буларак билгеле.

Альберт Яхин 1931 елның 8 ноябрендә Татарстан Республикасының Арча районы Арча поселогында хезмәткәр гаиләсендә дөньяга килә. Гаилә Азнакай районына күченеп, 1949 елда ул әлеге районның Тымытык урта 
мәктәбен тәмамлый. Шул ук елны В.И. Ульянов-Ленин исемендәге Казан дәүләт университетының татар теле һәм әдәбияты бүлегенә укырга керә. Югары белем алганнан соң, ул кабат үзе белем алган Тымытык урта мәктәбенә эшкә кайтып, ике ел уку-укыту эшләре буенча директор урынбасары булып эшли. Әмма фәнни эзләнүләргә омтылыш А. Яхинны кабат университет диварларына кайтара: 1956-1959 еллар аралыгында ул Казан дәүләт университетының татар әдәбияты кафедрасы каршындагы аспирантурада белем ала. Шул елларда ук фәнни мәкаләләр, язмалар белән республикакүләм матбугат чараларында чыгышлар ясый башлый, үткен фикерле тәнкыйтьче булып таныла. Аспирантурадан соң хезмәт юлын әүвәл журналистика белән бәйли. 1959 елда А. Яхин республиканың билгеле сатирик журналы «Чаян»га эшкә килә: 1959-1968 елларда аның жаваплы сәркатибе булып эшли, 1968 елдан 1975 елга кадәр баш мөхәррир вазифасын башкара [Әдипләребез, б. 725]. 1973 елда аның матбугат өлкәсендәге хезмәте РСФСРның атказанган мәдәният хезмәткәре дигән мактаулы исем белән бәяләнә. Журналистика өлкәсендә жаваплы вазифалар үтәсә дә, ул фәнни эзләнүләрен туктатмый, 1964 елда «Шамил Усманов ижаты» дигән темага кандидатлык диссертациясен яклый. Соңрак А. Гыйләжев белән берлектә «Шамил Усманов» (1966-1967) драмасын ижат итә. Бу әсәр 1967 елда Г. Камал исемендәге Татар дәүләт академия театрында сәхнәгә куелып, озак еллар уңыш белән бара һәм театр тәнкыйтьчеләре тарафыннан югары бәя ала.

Шушы дәвердә А. Яхин язучылык эше белән дә актив шөгыльләнеп китә, аның үткен фикерле, көн кадагына суккан сатирик хикәяләре һәм фельетоннары «Чаян», рус телендәге «Крокодил», Башкортстанның «Сәнәк» журналларында, «Көлке куа килә», «Күңелле сәхнә» кебек күмәк жыентыкларда басыла. 1975 елда аның «Әйттем исә кайттым», 1978 елда «Полный порядок» китаплары укучыга килеп ирешә. 1977 елда СССР Язучылар берлегенә кабул ителүе дә әдип буларак танылуын һәм бәяләнүен дәлилли.

1975 елда А. Яхин Казан дәүләт университетына татар әдәбияты кафедрасы мөдире итеп эшкә чакырыла һәм 1981 елга кадәр шушы кафедра белән житәкчелек итә. 1981 елдан тулысынча укыту эшенә күчә һәм фәнни юнәлештә эзләнүләрен активлаштыра. 1990 елда яңа гына ачылган татар филологиясе һәм көнчыгыш телләре факультетында татар телен hәм әдәбиятын укыту методикасы кафедрасы оештырыла. 1991 елда А. Яхин шул кафедрага күчеп, лаеклы ялга киткәнгә кадәр 1920-30 еллар татар әдәбияты тарихы курсын укыта, әдәби әсәр анализына бәйле махсус курслар эшли.

Галим 2010 елның 2 октябрендә Казанда вафат була.

А. Яхин әдәбият белеменә узган гасырның алтмышынчы елларында килә һәм халык авыз ижаты жанрларын, әдәби әсәрне тикшерүгә мөнәсәбәтле чыгышлары, фәнни мәкаләләре, хезмәтләре белән үзен теоретик әзерлекле, беркемне дә кабатламаган оригиналь, концептуаль карашлы, яңача фикерләүгә омтылучы әдәбият галиме итеп таныта. Аның фәнни калыплашуына шул елларда актуальләшеп киткән структурализм теориясе зур йогынты ясый. 1970 еллар уртасында, Тарту-Мәскәу семиотик мәктәбе тикшеренүләрен дәвам итеп, Казан дәүләт университетында Й.Г. Нигъмәтуллина житәкчелегендә әдәбиятны һәм сәнгатьне структур-семиотик өйрәнү юнәлеше киң колач жәя [Нигматуллина, б. 251]. Бу эшкә А. Яхин да жәлеп ителә һәм тикшеренүләрен шушы юнәлештәге концептуаль нигездә оештыра башлый. Галим төп өйрәнү объекты итеп, фольклорны сайлап ала һәм аны бербөтен система буларак өйрәнүнең яңа юлларын эзли. Әлеге эзләнүләренең төп нәтижәләрен ул М. Бакиров белән берлектә эшләгән «Фольклор жанрларын система итеп тикшеру тәжрибәсе» (1979), М. Мәһдиев белән автордашлыкта чыккан «Халык ижаты әсәрләрен система итеп тикшерү тәжрибәсе» (1982) китапларында тәкъдим итә. Бу китаплар жәмәгатьчелек тарафыннан югары бәяләнә һәм фольклористика фәнендә яңа сүз буларак кабул ителә.

Халык авыз ижатын өйрәнү юлындагы эзләнүләрен алга таба да дәвам итеп, 1984 елда А. Яхин «Система татарского фольклора» монографиясен бастыра. Галим татар әдәбият белемендә беренче тапкыр Ю.М. Лотман тәкъдим иткән структур анализ методы нигезендә татар фольклорын үсеш-үзгәрештәге бербөтен система буларак тикшереп чыга. Халык авыз ижатын әдәбият нәзариясе, фәлсәфә, социология, эстетика, психология кебек фәннәр белән бәйләнештә өйрәнү аша кызыклы нәтижәләр ясый, татар әдәбият белеме өчен өр-яңа фикерләр тәкъдим итә. Система hәм подсистема бүленешенә, вертикаль һәм әсәр структурасындагы горизонталь дәрәжәләргә таянып, жыр, табышмак, мәкаль һәм 
әйтем, бәет h.б. фольклор жанрларын, аларга хас үзенчәлекләрне теоретик аспектта төгәлләштерә [Мотигуллина, Гайнуллина, б. 313]. Монографиянең икенче өлешендә Үз фикерләрен конкрет фольклор жанрларына анализ аша дәлилли, бу хезмәтнең гамәли әһәмиятен тагын да арттыра. А. Яхинның бу монографиясе бүген дә фольклор теориясен өйрәнү юлында актуаль булып кала. Үзенең бу юнәлештәге эзләнүләрен ул соңрак «Хәзинә» сериясендә дөнья күргән китапларда да үстерә, камилләштерә.

1990 еллар башында А. Яхин методик эзләнүләр спектрын киңәйтә. Шушы елларда башланып киткән үзгәреш жилләре татар әдәбияты дәреслекләрен, аларның эчтәлеген үзгәртүне көн тәртибенә куя. Шушы ихтыяжны яхшы тойган А. Яхин 1991 елдан үз тирәсенә фикердәш укытучыларны туплап, татар телендә белем бирүче урта мәктәпләрнең 5-11 сыйныфлары өчен дәреслек, методик кулланмалар әзерләү эшенә керешеп китә. 2003-2004 елларда башлангыч сыйныфлар өчен дә укыту программасы hәм дәреслекләре дөнья күрә. Әмма альтернатив карашлы, әдәби әсәрне һәм, гомумән, әдәбиятны структур метод нигезендә өйрәнүгә йөз тоткан бу программа, дәреслекләрне мәктәп практикасына кертеп жибәру жиңелләрдән булмый. Программа һәм дәреслекләрнең ул вакытта кызу бәхәсләр үзәгенә әверелүе үзе үк шуны дәлилли. Ачык фикерле галим программа эшләү һәм шуңа таянган дәреслекләр язу белән генә чикләнми, Питрәч районы Шәле мәктәбе базасында Ү3 дәреслекләрен шәхсән үзе апробацияли дә. Университетта укыту белән параллель рәвештә Y3 дәреслекләре нигезендә Шәле мәктәбендә татар әдәбияты дәресләрен алып бара, укыту барышында аларны камилләштерә, шуннан соң гына республика күләмендә кулланылышка тәкъдим итә. Дистә еллар дәвамында А. Яхин программасы нигезендә эшләүче укытучылар белән даими төстә республикакүләм методик семинарлар оештыра.

А. Яхин тәкъдим иткән программа һәм дәреслекләр татар әдәбиятын укытуны концептуаль үзгәртә: ул укучының мөстәкыйль логик фикерләү сәләтен үстерүгә, әдәби әсәрне бербөтен берәмлек итеп кабул итүгә һәм аны структур-семиотик анализлауга корыла. Шуның аша укучы әдәби әсәрне ниндидер вакыйга сөйләнгән текст итеп түгел, камил төзелешкә ия, эчке компонентлары бер-берсенә тыгыз бәйләнгән, күпкатламлы берәмлек буларак кабул итә, аңа «яңа күз» белән карый башлый, автор фикеренең айсберг кебек тирәнгә яшеренгән икәнлегенә төшенә. Гадидән катлаулыга принцибы аша әдәби әсәрдән әдип ижатын, аннан әдәби чорны һәм әдәби барышны анализлауга йөз тота. 5-6 сыйныфларда укучылар әдәби әсәргә кагылышлы теорияне өйрәнә, аны аерым әсәрләргә анализ аша үзләштерә. 7-8 сыйныфларда әдәби ижатларны характерлаучы теоретик белем үзләштерелә башлый, шушы нигездә әдипләр ижаты, теге яки бу әдипнең фикерләү юллары, язу стиле өйрәнелә, 9-11 сыйныфларда әдәби чорларны бәяләргә терәк булган төшенчәләр өйрәнү үзәгенә куела һәм әдәби барыш үсеш-үзгәрештә тәкъдим ителә. Шул рәвешле укучыларда татар әдәбияты хакында системалы, комплекслы белем формалаштыру күздә тотыла, әдәби әсәрне анализлау күнекмәләре камилләшә. Әнә шулай А. Яхин татар әдәбият белемендә һәм методикасында Үз мәктәбен булдыра, яңа һәм үзгә концептуаль фикерләрне яңгырата.

\section{Әдәбият}

Әдипләребез: Библиографик белешмәлек: 2 томда: Т.2 / төз. Р.Н.Даутов, Р.Н.Рахмани. Казан: Татар. кит. нәшр., 2009. 735 б.

Мотигуллина А.Р., Гайнуллина Г.Р. Вклад А. Яхина в развитие методики преподавания татарской литературы в школе // Филология и культура. Philology and culture. 2016. № 4 (46). C. 311-317

Нигматуллина Ю.Г. Системно-комплексное исследование художественного творчества: история научного направления в Казанском университете. Казань: Фән, 2004. $251 \mathrm{c}$.

Яхин А. Әйттем исә кайттым: Сатирик хикәяләр һәм әкиятләр. Казан: Тат. кит. нәшр., 1975. 192 б.

Яхин А. Полный порядок: рассказы / Пер. с татар. С. Оффенгендена. Казань: Татар. кн. изд-во, $1978.95 \mathrm{c}$.

Яхин А., Бакиров М. Фольклор жанрларын система итеп тикшеру тәжрибәсе: (Мәзәкләр, бәетләр). Казан: Казан ун-ты нәшр., 1979. 198 б.

Яхин А., Мәһдиев М. «Халык ижаты әсәрләрен система итеп тикшеру тәжрибәсе» (Мәкаль, табышмак, жырлар). Казан: Казан ун-ты нәшр., 1982. 112 б.

Яхин А.Г. Система татарского фольклора. Казань: Тат. кн. изд-во, 1984. 200 с.

Яхин А.Г. Әдәбият дәресләре: Укытучылыр, югары уку йортлары студентлары, укучылар өчен методик кулланма. Казан: Мәгариф, 2003. 157 б. 